\title{
NOTES ON GEOMETRIDÆ.
}

PY A. R. GROTE,

Director of the Museum, Buffalo Socicty Natural Sciences.

Endropia serrata Grote \& Robinson, Trans. Am. Ent. Soc, p. 88 (July, ז868).

Geometra serrata Drury, Ill., I, 40, pl. 20, fig. 4 (1770).

Ennomos concisaria Walk., Part xxxv, I55 I (1866).

Endropia semataria Pack., 5 I 7, pl. I2, fig. 25 (1876).

Northern Illinois, June 25, Dr. Wm. A. Nason. This species seems to range from the Fastern and Middle States to Nebraska, according to Dr. Packard.

Lythria chamaechrysaria.

Mellita chamaechrysaria Grote, Bull. Buff. Soc. Nat. Sci., I, I3, pi. I, figs. $\mathbf{r}-3$.

Lythria rilevaria Pack., p. 22 I, pl. 9, fig. 43 .

I do not see any reason for not uniting these species; my illustration has apparently been overlooked by Dr. Packard.

Selenic Kentaria Grote \& Robinson, Trans. Am. Fnt. Soc,, I, 359, I865.

Pericallia Kentaria G. \& R., iv., I, I 2 , figs. 5-6 \&, 1867,

It is compared by us with the European Selenia illinaria, but our material of the latter was erroneously determined, hence the mistake in the generic name afterwards corrected by ourselves.

Tetracis lorata Grote, Proc. Ent. Soc. Phil., 3, 91, I864.

Dr. Packard has overlooked the original citation to this species.

Lobophora fusifasciata Walk., C. B. M., Part 24, I $25^{8}$ (1862).

Larentia longipennis Walk., Part 35, p. I67 I (1866).

Scotosia lobophorata Walk., 25, I347 (I862).

Lobophora vernata Pack., 5th Rep. Peab. Acad. Sci., 57 (I873).

Lobophora vernata Pack., Phal., I83, pl. 8, fig. 13 (เ876). 
Eupithecia fusifasciata G. \& R., Trans. Am. Ent. Soc., 2, 82 (1868).

On my visit to the British Museum specimens of this species were registered under different names, the first of which should, I think, stand for the species.

Lobophora atroliturata Walk, C. B. M., 25, 7710 (I862).

Eupethecia geminata Grote, Proc. Ent. Soc. Phil., 6, 29, pl. 5, fig. 6 (i866).

Lobophora geminata Pack., Phal., I84, Plate 8, fig. I4 (1876).

Eupithecia atroliturata G. \& R., Trans. Am. Fnt. Soc., 2, 83 (I868).

Fresh specimens are green tinted, when faded become yellow, then probably white as described by Professor Packard, who overlooks, apparently, our synonymical reference based on an examination of the British Museum collection.

\section{Choerodes Gueneé.}

This generic name must, I think, stand. The type of Eutrapela is the European lunaria. The question as to the generic distinction of clemitaria does not interfere, for if it is ultimately separated, it must receive a distinct name. Gueneé used Eutrapela Hübn. ex. Verz.

The species not referred to Choerodes as yet are, apparently, C. falcata (Pack.) and C. fusciferata (Pack.)

\section{Eutrapela Hübn., Tent.}

The type of this genus being the European Lunaria, our two North American species Eutr. Kentaria (G. \& R.) and Eutr. alciphearia (Walk.) must be referred to it.

Ennomos Treits.

The term Eugonia Hübn. is pre-occupied in the butterflies. I had proposed Eriplatymetra for coloradaria and angularia. According to Dr. Packard (I have no specimens) my coloradaria is a Tetracis.

Eubyja paenulataria (Grote), I’roc. Ent. Soc. Phil., 2, 3I, pl. 2, fig. 3 (1863).

This species is omitted by Dr. Packard. I think bis specimen from Dr. Perley (p. 413) may belong here. I believed to identify the $\hat{\sigma} E$. quernaria in coll. Mr. Saunders, but have now no specimens of this or paenulataria or cupidaria to compare. 
Endropia Wopieri.

Enaropic Warlieri Harvey, Bull. Buff. Soc. Nat. Sci, 2, r2 I (1874).

Enaropia apiciaria Pack., Phal., 502, Plate т2, fig. 9 (1876).

It is doubtless by an inintentional oversight that Ir. Packard has re-described this species.

Brotis whlneraria Hubn., Zutr.

A drawing, which I recognize as of this species, has been shown me by Prof. Hinstale of Racine. Wis., where the original was taken. Hubner describes the suecies as from Bahia. I would not refer it to the Geometra but to ne voctiat (fasciate)

\section{Plagoutis Kentzing (rrori.}

I)r. Packard changes the termination of the specific name. I do not think that anything is garen bye adirion of aria or ato to the specific names in this group: sro brint there is every reason why the specinc: name should be left is mitcr by the original author. And why, in the same genus, some names houid stand with aria arter then and some with ata, I cannot see (e. g. Semiothisa). If Eud. serrata should have a different termination on account of the pectinated antennae of the male, it Ghould be smaria, one would think, and not serrataria. Since the limit beween feathered and smpit antennae is very difficuit to draw, the correct application of these termination is nearly impossible

\section{NFW N(OCTIJ)A}

BY LION F, HARYFY, M. D., BUFTALO, N.

Manestra orobia, n. s.

Exes hairy; antenne pectinate. 'Thorax and wings grayish fuscous, color of trifoliz: basal half line white, i. a. line genin rte, widely separated ; t. p. line consisting of a suries of white points; subterminal irregular, terminal line black. Orbicular spot large, white ringed with dark centre; reniform constricted at the centre, white margined with a dark filling. Subterminal space shaded light. Beneath of a lighter shade, discal spot and a faint trace of the t. p. line. Secondaries shining fuscous, fringes whitish, beneath lighter, discal spot black, very evident. Expanse 20 m. m. Texas (O. Meske) 